Text and Canon of the Hebrew Bible 
This page intentionally left blank. 


\section{Text and Canon of the Hebrew Bible}

Collected Studies

Shemaryahu Talmon

Published in cooperation with

The MANDEL Institute OF JeWISH STUdies

The Hebrew University of Jerusalem

by

EISENBRAUNS

Winona Lake, Indiana

2010 
(C) 2010 by Eisenbrauns

Winona Lake, Indiana

All rights reserved.

Printed in the United States of America.

Published in Cooperation with

The Mandel Institute of Jewish Studies

The Hebrew University of Jerusalem

www.eisenbrauns.com

\section{Library of Congress Cataloging-in-Publication Data}

Talmon, Shemaryahu, 1920-

Text and canon of the Hebrew Bible : collected studies / Shemaryahu Talmon.

p. $\mathrm{cm}$.

"Published in cooperation with the Mandel Institute of Jewish Studies, the Hebrew University of Jerusalem."

Includes bibliographical references and indexes.

ISBN 978-1-57506-192-4 (hardback : alk. paper)

1. Bible. O.T.-Criticism, Textual. 2. Dead Sea scrolls. I. Mandel Institute of Jewish Studies (Jerusalem) II. Title.

BS1136.T325 2010

$221.6^{\prime} 6-\mathrm{dc} 22$

The paper used in this publication meets the minimum requirements of the American National Standard for Information Sciences-Permanence of Paper for Printed Library Materials, ANSI Z39.48-1984.@ ${ }^{\mathrm{Tm}}$ 